У, $\mathrm{K} 343.7$

ББК 67.408.12

DOI 10.22394/1682-2358-2020-4-17-23

O.A. Korotkova, Candidate of Sciences (Law), Docent of the Theory and History of State and Law Department, Kaluga State University named after K.E. Tsiolkovsky

I.A. Ovchinnikova, master's student of Kaluga State University named after K.E. Tsiolkovsky

\section{PRACTICE \\ OF PREVENTING \\ CORRUPTION \\ IN EDUCATION: \\ EXPERIENCE OF DENMARK}

Specifics of the fight against corruption in education in Denmark is analyzed. Various methods of preventing corruption implemented in Denmark are investigated. It is emphasized that it is impossible to fight corruption in education within a single country without taking into account the existing experience. Based on the practice of Denmark practical recommendations on measures to effectively prevent corruption are given.

Key words and word-combinations: corruption, education, anti-corruption foreign experience, Denmark.
O.A. КороткоЊа, кандидат юориических наук, дочент кафедри теории и истории государства и права Калужского государственного университета им. К.Э. Циолковского (email: KorotkovaOA@tksu.ru)

И.А. ОВчинникова, магистрант Калужского государственного университета им. К.Э. Циолковского (email:starostin.chk@yandex.ru)

\section{ПРАКТИКА \\ ПРЕАУПРЕЖАЕНИЯ \\ КОРРУПЦИИ \\ В СФЕРЕ ОБРАЗОВАНИЯ: ОПЫТ ААНИИ}

Аннотащия. Проанализирована специфика борьбы с коррупцией в сфере образования в Дании.

Исследуются различные методы предупреждения коррупции, реализуемые в стране. Подчеркивается, что эффективно бороться с коррупцией в сфере образования в рамках отдельно взятой страны невозможно без учета имеющегося опыта. Даются практические рекомендации по мерам эффективного предупреждения коррупции на основе практики Дании.

Ключевые слова и словосочетания: коррупция, сфера образования, антикоррупционный зарубежный опыт, Дания.

$\Gamma$ обальной проблемой на уровне не ТОАЬКО ОАНОГО ОтАеАьНО взятоГо ГОсУАарства, но и на межаународном уровне явмяется коррупџия. Анациз развития госуАмарственного управления в мире позвоцяет сделать вывод, что коррупция - неотъем- 
мемое явление государственного управления, присущее Аюбому обществу $[1$, c. 46$]$.

К сожалению, не изобрели еще чудодейственную вакцину от болезни под названием «коррупция», которая сопровождает человечество на протяжении не одной тысячи мет. Иммунитет, подаренный цюдям природой на такое явление, как коррупция, также не выработался. Тем временем болезнь продолжает заражать страны, каждый раз вызывая все новые и новые симптомы.

Коррупџия как антисоџиальное явление существовала еще до появления государства и аппарата государственных служащих. По-видимому, семя коррупции, ранее спокойно Аремлюшее в глубинах человеческой Ауши, «проснулось» и начало пускать корни в институт власти, затрагивая важнейшие вопросы, касающиеся соџиальной справедливости и использования материальных благ.

Несмотря на столь долгий период существования исследуемого явления, термин «коррупция» появился относительно недавно. Существуют Аве гипотезы возникновения исследуемого понятия. Согласно первой, термин «коррупџия» (от мат. «соrruptio») обязан появмению римскому праву и образова ся в результате сочетания приставки «сог» и многозначного глагола «rumpere», имеющего значения «рвать», «ломать», «разрушать,, «пронзать», «проламывать», а также «нарушать мир», «расторгать договор», «преступать закон». Аанная дефиниџия обозначала деятельность двух или более миџ, направленную на нарушение принятого хода управления деками или судебного проџесса $[2$, c. 8$]$.

Согласно второй версии, матинский термин произошел от греческого слова «грязь», также явмяющегося многозначным. В качестве примера можно привести такие его значения, как «искажать смыск», «унижать достоинство», «фальсифицировать результаты».

Изучение явления коррупции в последнее время породияо широкие дискуссии по поводу определения этого понятия, системности проявлений, неотъемлемых признаков. Среди многообразного спектра мнений относительно коррупщии до сих пор не выработано единого, общепризнанного, «классического» определения, которое имело бы четкую, полную и непротиворечивую оценку явления коррупщии [3, с. 7].

В зарубежных странах сушествует множество определений исследуемого явления. Так, коррупџия рассматривается как соџиальная проблема, в определенной степени и форме присутствующая на всех этапах развития общества и достигающая расщвета в Аоиндустриальном обществе [4, с. 40], Аибо как незаконное использование должностным Аицом государственной власти, направленное в угоду как себе, так и другому мицу, и состоящее в обогашении или продмении срока полномочий за счет общественных интересов посредством нарушения принятой кАятвы и / или совершения действий, входящих в противоречие с принятыми конвенциями и законами [5, с. 28].

Merriam-Webster Dictionary определяет коррупцию как нарушение моральных принципов, социальной справедливости и добродетели, отно- 
сящееся к неэтичному поведению на всех уровнях властных структур общества [6] .

В российском законодательстве определение коррупции представляет собой перечисление составов преступлений, предусмотренных Уголовным кодексом РФ. Коррупция поражает все сферы жизнедеятельности социального организма и в конечном счете может привести к параличу общественной жизни. Наиболее опасна коррупџия Аля «несущих конструкций» современного общества, к которым, несомненно, относится образование. К сожалению, современное отечественное законодательство не предусматривает дефиниции коррупции в сфере образования.

Нормативно-правовое определение коррупции в сфере образования дает ЮНЕСКО. Так, поА коррупџией в указанной сфере понимается систематическое использование пубцичной должности в частных интересах, существенно влияющее на доступность, качество и объективность в образовании [7, с. 7-8]. Коррупция в образовательной сфере включает в себя отношения не только преподавателя и обучающегося. Опасное заболевание поражает систему образования несколькими способами: через образовательные функции; поставку товаров и услуг дия школьных нужА; ненадлежащее исполнение служебнных обязанностей; а также путем налогообложения и имущественных отношений [5, с. 1309].

При анализе данных понятий прослежкивается традиционная связь с более ранними определениями, затрагивающими причины неправомерного поведения. К примеру, Аревнеримский философ Гален выводит понятие коррупции через три составцяющих: «мень и праздность Ауха», «ненасытную жажду Аенег», «небрежение обязательствами» [8, с. 262]. К перечисленным «Авижущим симам» исследуемой дефиниџии следует Аобавить «жажду власти». Как более общее явление она способна объяснить мотивы человеческого поведения, материальным следствием которого является коррупция.

Несмотря на обширную территорию распространения коррупџионной болезни, вцияние, которое она оказывает, неодинаково в разных регионах планеты. По мнению И.Ю. Чивирева, «коррупџия в международно-правовых актах определяется как одна из глобальных проблем в сфере обеспечения межаународного правопорядка. МежАународное сообщество стремится к объединению усилий в Аеле преАупреждения и пресечения коррупџии» [9, с. 8] . А.Г. Федоров, В.К. Крутиков, С.В. Шаров утверждают, что, «только преодолев разногласия и противоречия в существующих ныне законодательных системах разцичных стран мира, можно обеспечить эффективность борьбы с коррупцией» $[10$, с. 206].

Согласно статистическим данным «Transparency International» за 2019 г., средний индекс восприятия коррупџии в странах Европейского Союза и Западной Европы равен 66 (при 100-баммьной шкале оџенки), в то время как на Ближнем Востоке и Северной Африке этот индекс равен 39, в странах Субсахарской Африки - 32, в странах Азиатско-Тихоокеанского 
региона - 45, в странах Восточной Европы и Центральной Азии - 35, в странах Америки - 43.

С 2012 г. только 22 страны улучшили свои антикоррупционные показатеми, в их числе Греция, Гайана, Эстония. За этот же период 21 страна ухудшила свои показатели, а остальные страны не достигли какого-либо существенного прогресса.

Странами-лидерами в борьбе с коррупцией явмяются Аания $(87 / 100)$, Новая Зеландия (87/100), Финияндия (86/100), замыкают первую шестерку Сингапур, Швеция, Швейцария с одинаковым индексом $(85 / 100)$. Столь высокие показатели свидетельствуют о том, что эти страны принимают комплексные меры по противодействию коррупџии во всех отраслях, в том числе и в сфере образования [11]. УАивительно, но выработанной наџиональной стратегии борьбы с коррупџией в сфере образования у стран-лидеров нет: высокие результаты достигаются в большинстве своем за счет превентивных мер. Именно поэтому представцяется необходимым детально изучить антикоррупџионный опыт в сфере образования одной из стран-лидеров в борьбе с коррупџией - Аании.

Среди причин, по которым Аания занимает мидирующую позицию, выдемим следующие:

1. Взаимодействие трех систем: законодательной, правоохранительной (исполнительной) и судебной. Особое внимание следует уделить законодательной системе, ведь "свобода есть право делать все, что дозволено законами» (Ш. Монтескье). Совершенство Аатского законодательства проявмяется в его соответствии международному законодательству по вопросам борьбы с коррупцией. Так, законодательная система Аании охватывает все виды коррупции, предусмотренные Конвенцией Совета Европы об угомовной ответственности за коррупџию и дополнительным протоколом, за исключением ст. 12, повествующей о змоупотреблении влиянием в корыстных целях [12]. Кроме того, в стране функционируют порядка двадцати законов, предусматривающих ответственность за коррупщионные преступмения.

В Уголовном кодексе Аании проводится разцичие между подкупом Аолжностных и частных миџ и выдемяются следуюшие виды взяточничества: «публичный активный подкуп» (ст. 122), «публичный пассивный поАкуп» (ст. 144) и «частный подкуп» (ст. 299 (2)) - как активный, так и пассивный [13] .

Первые Ава вида затрагивают понятие домжностного мица, которое трактуется широко, в соответствии с ратифицированной Аанией Конвенщией. ПоА публичным Аолжностным Аиџом в этом случае понимается миџо, избранное, нанятое или действующее от имени мюбого датского как государственного, так и муниципального органа, а также миџо, имеющее аналогичные отношения мибо с иностранным государством, Аибо с международной организацией (например, ООН или НАТО).

Третий виА регулирует взяточничество в частном секторе. Следует отметить, что подобное разграничение позволяет действовать точечно на проблем- 
ные очаги, в том числе и в сфере образования, так как затрагивает не только публичных Аолжностных, но и частных миц.

Меры наказания за коррупционные нарушения ужесточились в последние годы. Так, ст. 122 УК Аании предусматривает штраф или мишение свободы на срок до трех мет. Срок мишения свободы по ст. 144 УК Аании увеличился Ао шести мет. Наказание по ст. 299 (2) теперь составмяет штраф и мишение свободы на срок до одного года шести месяџев [13].

2. Отсутствие специального государственного антикоррупционного ведомства, в связи с чем расследование коррупџионных преступцений ведут правоохранитемьные органы.

3. Принџип прозрачности. Суть данного принџипа, нашедшего отражение в законодательной базе (Закон о коррупџии 2002 г.), заключается в обязывании представителей Аатского правительства, вкмючая министров, декларировать свои доходы и предоставмять сведения об имеющимся в их собственности имушестве. В соответствии с Аанным Законом государственным скужащим запрещается иметь акщии иностранных компаний. Система сдержек и противовесов Аополняется правом мюбого чиена Аатского пармамента на получение информаџии относительно деятельности министров. Так, во время парламентских заседаний министры, в числе которых и министр по делам детей и образования, оглашают отчеты, которые сопровожАаются вопросами относительно подозрений в их участии в коррупционных связях. Аیя развития системы образования это имеет решающее значение, так как данная сфера по большей части финансируется из государственного бюджета, поэтому важно, чтобы выделенные средства доходили до истинного адресата.

Более того, Аатское законодательство предусматривает возможность анонимного сообщения о коррупџионном преступцении.

4. Принцип взаимодействия. Суть данного принципа заключается в совместной борьбе пубцичного и частного секторов против коррупџии, что реализуется посреАством заключения специальных антикоррупџионных соглашений. Основной груз работы можится на плечи Торгового совета Аании и Агентства международного развития (DANIDA), которое даже заключает декларацию о «неприменении взяток». Таким образом, нарушившая декларацию компания не только теряет имидж, но и мишается многих выгодных контрактов. Исследуемый в данной статье принџип крайне важен для сферы образования, так как одной из главных задач страны является привлечение внешних инвестиџий в сферу национального образования.

Реализация принципов прозрачности и взаимодействия Аает серьезную гарантию иностранным инвесторам дмя вложения капитала.

5. «Zero tolerance» означает политику «абсолютной нетерпимости» по отношению ко всем формам коррупции [14]. Реализуется данная политика бкагодаря правовому воспитанию, которое предусматривает укрепление норм нравственности; разработку этических кодексов служебного поведения; формирование правовой культуры мичности с раннего возраста; следование принципам открытости, честности, прозрачности. 
Помимо «общих» Аатских положений, можно выделить положительные особенности в борьбе с коррупщией, присущие системе наџионального образования. Они заключаются в основном в простоте организационной структуры. Так, Министерство образования Аании состоит из министра, постоянного секретаря и двух ведомств, информацию о которых можно без труда обнаружить на офиџиальном сайте Министерства. Следует отметить также четкое разделение полномочий различных подразделений.

Важную роль играет постоянный контроль, который проявляется в двух

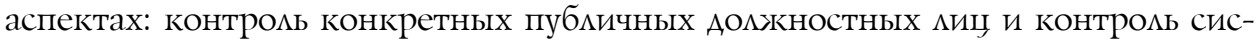
темы образования в цемом. Последний осуществляется за счет созданной в 2011 г. национальной консультационной системы в сфере образования (Guidance in Education), которая нацелена на предоставление данного рода услуг киџам в основном в возрасте до 25 мет, однако консультаџию могут получить абсолютно все, независимо от возраста. Работа консультационных центров заключается в предоставлении информации не только о возможностях обучения, но и о возможностях трудоустройства, а также совмещения обучения и работы. ОАним из плюсов Аанной системы явцяется возможность получения консультации, не выходя из дома - посреАством мессенджеров или мюбым Аругим удобным способом. Представляется, что такая система предотврашает развитие коррупции в образовательной сфере, так как, во-первых, дает объективную информацию, а, во-вторых, препятствует трудоустройству «по блату» $[15$, c. 4$]$.

Контроль системы наџионального образования осуществцяется также посредством финансирования не только государственных, но и частных образовательных учреждений. Финансирование частных образовательных учреждений - это мера превентивного характера против коррупции. Финансирование осуществцяется посредством системы соџиальных грантов, получить которые частная школа можкет в случае, если удовлетворяет требованиям, которые предъявцяет Министерство образования Аании, а именно:

- минимальное количество учеников в 1-7 классах (не менее 28), 12 учеников - в первый гоА существования школы и 20 - во второй;

- запрет на расходование средств не на благо самой школы;

- школа не должна принадлежать частному мицу или функционировать Аля частной прибыли;

- школа должна быть самоуправцяющимся учрежжением, в котором Аолжен действовать не только совет управцяющих, подотчетный Министерству образования, но и регламент использования мюбых чистых активов в случае миквидации школы.

Аанные меры полностью исключают возможность «отмывания денежных среАств» в частном образовательном секторе Аании.

Превентивными мерами можно считать запрет частных высших образовательных учреждений, а также возможность получения бесплатного образования Амя государственных служащих [16] .

Аостаточно скромный размер заработной платы государственных служа- 
щих, в том числе в сфере образования, явмяется фактором, обеспечивающим приток кадров, обладающих наиболее нравственным психотипом и готовых служить на благо всего общества [17]. Вопрос о размере заработных плат сегодня в стране остается открытым, при этом учитывается опыт борьбы с коррупщией в Сингапуре, где доходы граждан в сфере образования довольно высокие.

Таким образом, анализ антикоррупционного опыта Аании в сфере образования свидетельствует, что он носит в большинстве своем превентивный характер и явмяется закономерным результатом непрерывной борьбы с коррупџией прежАе всего в государственном секторе.

\section{Библиографический список}

1. Короткова О.А., Соколов И.С. Коррупция как неотъемлемое явление государственного управления: исторический аспект // Закон и право. 2019. № 7. С. 46-49.

2. Бондаренко С.В. Коррумпированные общества. Ростов н/Д, 2002.

3. Петрушина O.М., Борзенкова А.B. Коррупция и борьба с ней в таможенных органах // Вестник Калужского университета. 2018. № 3. С. 7-12.

4. Staats Steven J. Corruption in the Soviet System // Problems of Communism. January 1972. P. $40-47$.

5. Plessis Pierre $d u$. Corruption in Education - Stealing the Future // Mediterranean Journal of Social Sciences. Rome - Italy: MCSER Publishing, November 2014. Vol. 5, № 23. P. 1308-1316.

6. Merriam-Webster Dictionary. URL: https://www.merriam-webster.com/dictionary/corruption

7. Chapman D. Corruption and the education sector. Sectoral Perspectives on Corruption. Washington, DC: USAID, Prepared by MSI, sponsored by USAID, DCHA/DG, 2002. URL: http://pdf. usaid.gov/pdf_docs/PNACT874.pdf.

8. Реале Д., Антисери Д. Западная философия от истоков до наших дней: в 4 т. Т. 1: Античность. М., 1994.

9. Чивирев И.Ю. Международный опыт борьбы с коррупцией и возможность применения этих методов в России // Скиф. Вопросы студенческой науки. 2017. № 6. С. 8-11.

10. Федоров А.Г., Крутиков В.К., Шаров С.В. Законодательное обеспечение эффективной борьбы с коррупцией и мошенничеством // Вестник Алтайской академии экономики и права. 2019. № 12. C. 201-207.

11. Corruption Perception Index 2019. Transparency International. URL: http:// www.transparency.org/cpi

12. Annex Denmark to the EU Anti-Corruption Report. European Commission Brussels, 3.2.2014 COM (2014) 38 final. URL: https://ru.scribd.com/document/387852273/2014-Acr-DenmarkChapter-En

13. Criminal Code of Denmark. URL: http//www.legislationline.org/documents/section/criminalcodes/country/34/Denmark/show

14. Ministry of Foreign Affairs of Denmark/anti-corruption Policy, October, 2018. URL: https:// um.dk/en/danida-en/about-danida/danida-transparency/anti-corruption/

15. Guidance in Education - the educational guidance system in Denmark. Published by Euroguidance Denmark, The Danish Agency for Higher Education, 2014.

16. Ministry of Education. URL: https://eng.uvm.dk/primary-and-lower-secondary-education/ private-schools-in-denmark

17. Barfort S., Harmon Nikolaj A., Hjorth F., Olsen Asmus Leth. Sustaining Honesty in Public Service: The Role of Selection // American Economic Journal: Economic Policy. 2019. Vol. 11 (4). P. 96-123. URL: https://www.aeaweb.org/articles?id=10.1257/pol.20170688. 